\title{
SYNTHESIS OF GERANYLHYDROQUINONE DERIVATIVES WITH POTENCIAL CYTOTOXIC ACTIVITY
}

\author{
Evelyn Baeza, Karen Catalán, Hugo Peña-Cortés and Luis Espinoza* \\ Departamento de Química, Universidad Técnica Federico Santa María, Valparaíso, Chile \\ Joan Villena \\ Facultad de Medicina, Universidad de Valparaíso / Centro Regional de Estudios en Alimentos Saludables, Valparaíso, Chile. \\ Héctor Carrasco \\ Departamento de Ciencias Químicas, Universidad Andrés Bello, Campus Viña del Mar, Chile
}

Recebido em 12/5/11; aceito em 29/8/11; publicado na web em 26/9/11

\begin{abstract}
Natural geranylhydroquinone 1 and geranyl-p-methoxyphenol 2 were prepared by Electrophilic Aromatic Substitution (EAS) reactions between geraniol and 1,4-hydroquinone or $p$-methoxyphenol respectively, using $\mathrm{BF}_{3} \cdot \mathrm{Et}_{2} \mathrm{O}$ as a catalyst. Furthermore, natural geranylquinone 3, geranyl-1,4-dimethoxyquinone $\mathbf{4}$ and the new geranyl-4-methoxyphenyl acetate $\mathbf{5}$ were obtained by chemical transformations of $\mathbf{1}$ and $\mathbf{2}$. The compounds were evaluated for their in vitro cytotoxicity activities against cultured human cancer cells of PC-3 human prostate cancer, MCF-7 and MDA-MB-231 breast carcinoma, and Dermal Human Fibroblasts DHF. IC s0 $_{\text {values }}$ were in the $\mu \mathrm{M}$ range.
\end{abstract}

Keywords: synthesis; geranylhydroquinones; cytotoxic activity.

\section{INTRODUCTION}

Polyprenylated 1,4-benzoquinones and hydroquinones such as ubiquinones, plastoquinones, and tocopherols are widely found in plants and animals, in which they play important roles in electron transport, photosynthesis, and as antioxidants. ${ }^{1}$ Prenyl benzoquinones have been also isolated from brown algae of the order Fucales, ${ }^{2}$ sponges, ${ }^{3}$ alcyonaceans, ${ }^{4}$ gorgonaceans, ${ }^{5}$ and ascidians belonging to the genus Aplidium. ${ }^{6}$ These substances present a terpenoid portion ranging from one to nine isoprene units. Brown algae contain diprenyl-, triprenyl-, as well as tetraprenylquinones and hydroquinones, ${ }^{2}$ where as sponges contain prenylated 1,4-benzoquinones and hydroquinones with linear and longer (up to nine isoprene units) terpenoid side chains. ${ }^{3}$ Ascidians of the genus Aplidium have previously yielded around a dozen prenylated quinones and related compounds. ${ }^{6}$ Studies on the relation structure activity (SAR) of a series of nonmethoxylated prenylated quinones, with side chains containing from one to eight isoprene units, using antimicrobial, brine shrimp lethality, and fish lethality assays, have demonstrated that the optimum length of the side-chain corresponds to two isoprene units in the terpenoid part. ${ }^{7}$ Another study of SAR investigating the cancer-preventive activity of a group of methoxylated prenylated quinones containing from one to four isoprene units reported that quinones having a side chain of 10 carbon atoms in length showed specificity in the inhibitory effect for transformed JB6 $\mathrm{P}^{+} \mathrm{Cl} 41$ cells. ${ }^{8}$ Due to these antecedents and as a continuation of our research, the current work describes the preparation and cytotoxic activity of prenyl benzoquinones and hydroquinones with two isoprene units, referred to as geranylhydroquinones derivatives (1-5). Two of these compounds, natural geranylhydroquinone 1 and geranyl- $p$-methoxyphenol 2, were synthesized using the strategy of Electrophilic Aromatic Substitution (EAS) reactions, according to protocol reported elsewhere. ${ }^{9}$ All the compounds were evaluated in vitro against cultured human cancer cells in order to analyse the influence of molecular structure on the cytotoxic activity.

*e-mail: luis.espinozac@usm.cl

\section{RESULTS AND DISCUSSION}

\section{Chemistry}

The strategy of Electrophilic Aromatic Substitution (EAS) was used in the coupling reaction for preparation of 2-((E)-3,7-dimethylocta-2,6-dienyl)benzene-1,4-diol (1) and 4-methoxy-2-((E)-3,7dimethylocta-2,6-dienyl)phenol (2), according to previously reported procedures. ${ }^{9}$ Chemical transformations of the coupling compounds $\mathbf{1}$ and $\mathbf{2}$ are summarized in Scheme 1. The structural determination of all the derivatives was accomplished mainly by IR, HRMS, ${ }^{1} \mathrm{H},{ }^{13} \mathrm{C}$, DEPT-135, gs-2D HSQC and gs-2D HMBC NMR techniques (2D correlation were registered only for some compounds). The ${ }^{1} \mathrm{H}-\mathrm{NMR}$ spectrum of $\mathbf{1}$ was compared with the spectral data reported for the isolated natural compound. ${ }^{10}$ This compound showed the existence of two hydroxyl groups at $\delta 4.75$ and 4.46 , and the presence of three aromatic hydrogens at $\delta 6.69(\mathrm{~d}, J=8.0 \mathrm{~Hz}, 1 \mathrm{H}, \mathrm{H}-6), 6.61(\mathrm{~d}, J=3.0$ $\mathrm{Hz} 1 \mathrm{H}, \mathrm{H}-3$ ), 6.58 (dd, $J=3.0$ and $8.0 \mathrm{~Hz}, 1 \mathrm{H}, \mathrm{H}-5$ ). In addition, the point of coupling was confirmed by the presence of the signal at $\delta 3.30$ (d, $J=7.0 \mathrm{~Hz}, 2 \mathrm{H}, \mathrm{H}-1^{\prime}$ '). The signals at $\delta 116.6$ (C-3), 113.7 (C-5), of three aromatic carbons and $26.4 \mathrm{ppm}\left(\mathrm{C}-1^{\prime}\right)$ in the ${ }^{13} \mathrm{C}-\mathrm{NMR}$ spectrum corroborated the molecular structure. On the ${ }^{1} \mathrm{H}-\mathrm{NMR}$ spectrum of geranyl-p-methoxyphenol 2, the signals at $\delta 3.75$ (s, 3H, H-8) of the methoxyl group, $\delta 3.33$ (d, $J=7.0,2 \mathrm{H}, \mathrm{H}-1^{\prime}$ ) of the point of coupling, $\delta 4.80(\mathrm{~s}, 1 \mathrm{H}, \mathrm{OH})$ of the phenol and three aromatic hydrogens at $\delta 6.74$ (d, $J=8.5 \mathrm{~Hz}, 1 \mathrm{H}, \mathrm{H}-6), 6.68$ (d, $J=3.0 \mathrm{~Hz}, 1 \mathrm{H}, \mathrm{H}-3), 6.65$ (dd, $J=8.5$ and $3.0 \mathrm{~Hz}, 1 \mathrm{H}, \mathrm{H}-5)$ were predominantly observed. On the ${ }^{13} \mathrm{C}-\mathrm{NMR}$ spectrum, the presence of the methoxyl group at $\delta 55.7\left(\mathrm{OCH}_{3}\right)$ as well as the signals of three aromatic carbons at $\delta 116.4$ (C-6), 115.7 (C-3), 112.1 (C-5), were also confirmed. (here the spectroscopic 2D NMR information of compound 2 was deleted). In addition, the configuration of the C2'-C3' double bond was compared with the chemical shifts of C-10' reported for similar compounds. ${ }^{11}$

The 2-((E)-3,7-dimethylocta-2,6-dienyl)cyclohexa-2,5-diene-1,4dione compound $\mathbf{3}$ was prepared by oxidation reaction of geranylhydroquinone 1 with $\mathrm{MnO}_{2}$, being an alternative method to that reported. ${ }^{12}$ The molecular structure was confirmed for the presence of the signals at $\delta 6.75(\mathrm{~d}, J=10.0 \mathrm{~Hz}, 1 \mathrm{H}, \mathrm{H}-6) ; 6.70(\mathrm{dd}, J=2.0$ and $10.0 \mathrm{~Hz}, 1 \mathrm{H}$, 
<smiles>CC(C)=CCCC(C)=CCO</smiles>

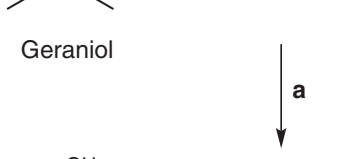<smiles>Oc1ccc(O)cc1</smiles>

$6 \mathrm{R}_{1}=\mathrm{H}$ $7 \mathrm{R}_{1}=\mathrm{CH}_{3}$<smiles>Oc1ccc(O)c(P)c1</smiles><smiles>COc1ccc(O)c(P)c1</smiles><smiles>O=C1C=CC(=O)C(P)=C1</smiles><smiles>COc1ccc(OC)c(P)c1</smiles><smiles>COc1ccc([N+](=O)[O-])cc1</smiles><smiles>CC=C(C)CCC=C(C)C</smiles>

Scheme 1. Synthesis of geranylhydroquinones derivatives: (a) dioxanel $\mathrm{BF}_{3} \mathrm{Et}_{2} \mathrm{O}, \mathrm{N}_{2}$, r.t.; (b) $\mathrm{MnO}_{2} / \mathrm{CH}_{2} \mathrm{Cl}_{2}$, r.t.; (c) $\left(\mathrm{CH}_{3}\right)_{2} \mathrm{SO}_{4} / \mathrm{K}_{2} \mathrm{CO}_{3}$, acetone, r.t.; (d) $\mathrm{Ac}_{2} \mathrm{O} / \mathrm{CH}_{2} \mathrm{Cl}_{2} / \mathrm{DMAP}$, r.t.

$\mathrm{H}-5) ; 6.52$ (dd, $J=2.0$ and $4.0 \mathrm{~Hz}, 1 \mathrm{H}, \mathrm{H}-3$ ) of the quinonic hydrogens in the ${ }^{1} \mathrm{H}-\mathrm{NMR}$ spectrum and for the existence of two carbonyl carbons at $\delta 187.9(\mathrm{C}-1), 187.6(\mathrm{C}-4)$ in the ${ }^{13} \mathrm{C}-\mathrm{NMR}$ spectrum.

The preparation of 1,4-dimethoxy-2-((E)-3,7-dimethylocta-2,6dienyl)benzene compound 4 was carried out by methylation reaction with $\left(\mathrm{CH}_{3}\right)_{2} \mathrm{SO}_{4}$ in relatively basic conditions of $\mathbf{1}$ or $\mathbf{2}$, as an alternative method to that reported. ${ }^{13}{ }^{1} \mathrm{H}-\mathrm{NMR}$ spectrum showed two singletes at $\delta 3.79$ and 3.76 , the signals corresponding to the methoxyl groups. These signals also were observed in the ${ }^{13} \mathrm{C}-\mathrm{NMR}$ spectrum at $\delta 56.1$ and 55.6.

To obtain 4-methoxy-2-((E)-3,7-dimethylocta-2,6-dienyl)phenyl acetate derivative 5, geranyl- $p$-methoxyphenol $\mathbf{2}$ was acetylated with acetic anhydride using dimethylaminopyridine (DMAP) as a catalyst. The molecular structure was corroborated by the signals at $\delta 2.29$ (s, $3 \mathrm{H}, \mathrm{H}-7), 20.8$ (C-7) and $169.9\left(\mathrm{COCH}_{3}\right)$ of the acetyl group, and their spectral data compared with geranyl-p-methoxyphenol 2.

\section{Bioactivity}

The cytotoxicity of the compounds was evaluated against three different cancer cell lines: PC-3 human prostate cancer, MCF-7 and MDA-MB-231 breast carcinoma, and one non-tumoral cell line, der- mal human fibroblasts (DHF), using in vitro analysis. A conventional colorimetric assay was set up to estimate the $\mathrm{IC}_{50}$ values representings the concentration of the drug, required for $50 \%$ inhibition in vitro after $72 \mathrm{~h}$ of continuous exposure to the test compounds. Four serial dilutions (from 12.5 to $100 \mu \mathrm{M}$ ) of each sample were evaluated in triplicate. The results obtained from these assays are shown in Table 1. The derivatives compounds $\mathbf{2}, \mathbf{4}$ and $\mathbf{5}$ did not affect the bioactivity of the cells lines studied. However, compounds $\mathbf{1}$ and $\mathbf{3}$ showed $\mathrm{IC}_{50}$ values with inhibitory activity in the $\mu \mathrm{M}$ range albeit lower than the positive control (Dunnione), where these values may be due to the presence of hydroquinone or quinone moiety. Moreover, compounds $\mathbf{1}$ and $\mathbf{3}$ displayed some selectivity for the cancer cells versus fibroblast cells, which could provide an approach to obtaining compounds with potentially lower toxicity in normal human cells.

Table 1. Cytotoxicity $\left(\mathrm{IC}_{50} \mu \mathrm{M}\right)$ of Geranylhydroquinones $\mathbf{1}$ and derivatives

\begin{tabular}{ccccc}
\hline Compound & PC-3 & MCF-7 & MDA-MB-231 & DHF \\
\hline 1 & 93,18 & 86,54 & 84,23 & $>100$ \\
2 & $>100$ & $>100$ & $>100$ & $>100$ \\
3 & 89,51 & 91,08 & 85,23 & $>100$ \\
4 & $>100$ & $>100$ & $>100$ & $>100$ \\
5 & $>100$ & $>100$ & $>100$ & $>100$ \\
Dunnione & 26.51 & 14.56 & 22.13 & 27.03 \\
\hline
\end{tabular}

\section{EXPERIMENTAL}

\section{General}

Unless otherwise stated, all chemical reagents purchased (Merck or Aldrich) were of the highest commercially available purity and were used without previous purification. IR spectra were recorded as thin films on a Nicolet Impact 420 spectrometer, and frequencies are reported in $\mathrm{cm}^{-1}$. High resolution mass spectra were recorded on an LTQ Orbitrap XL spectrometer by applying a voltage of 1.8 $\mathrm{kV}$ in the positive, and $1.9 \mathrm{kV}$ in the negative, ionization mode. The spectra were recorded using full scan mode, covering a mass range from $\mathrm{m} / \mathrm{z}, 100-1300$. The resolution was set to 50,000 and maximum loading time for the ICR cell was set to $250 \mathrm{~ms} .{ }^{1} \mathrm{H},{ }^{13} \mathrm{C}$, DEPT-135, sel. 1D ${ }^{1} \mathrm{H}$ NOESY, 2D HSQC and 2D HMBC spectra were recorded in $\mathrm{CDCl}_{3}$ solutions and were referenced to the residual peaks of $\mathrm{CHCl}_{3}$ at $\delta 7.26 \mathrm{ppm}$ and $\delta 77.0 \mathrm{ppm}$ for ${ }^{1} \mathrm{H}$ and ${ }^{13} \mathrm{C}$, respectively, on a Bruker Avance 400 digital NMR spectrometer, operating at $400.1 \mathrm{MHz}$ for ${ }^{1} \mathrm{H}$ and $100.6 \mathrm{MHz}$ for ${ }^{13} \mathrm{C}$. Chemical shifts were reported at $\delta$ ppm and coupling constants $(J)$ given in Hz. Silica gel (Merck 200-300 mesh) was used for C.C. and silica gel plates HF-254 for TLC. TLC spots were detected by heating after spraying with $25 \% \mathrm{H}_{2} \mathrm{SO}_{4}$ in $\mathrm{H}_{2} \mathrm{O}$.

\section{Chemistry}

General procedure for Electrophilic Aromatic Substitution (EAS), synthesis of compounds $\mathbf{1}, 2$

$\mathrm{BF}_{3} \cdot \mathrm{Et}_{2} \mathrm{O}(0.2300 \mathrm{~g}, 1.6 \mathrm{mmol})$ was gradually added at room temperature to a solution of 1,4-hydroquinone $(0.6012 \mathrm{~g}, 5.5 \mathrm{mmol})$ or $p$-methoxyphenol $(0.8749 \mathrm{~g}, 7.06 \mathrm{mmol})$ and geraniol $(0.8 \mathrm{~g}, 5.5$ mmol) in freshly distilled 1,4-dioxane $(20 \mathrm{~mL})$. The mixture was stirred at room temperature under a nitrogen atmosphere for $24 \mathrm{~h}$, after wich the completion of the reaction was verified by TLC. The mixture was poured onto crushed ice (about $30 \mathrm{~g}$ ) and the organic layer extracted with EtOAc $(3 \times 30 \mathrm{~mL})$. The combined organic phase 
was washed with $5 \% \mathrm{NaHCO}_{3}(30 \mathrm{~mL})$, then with water $(2 \times 20 \mathrm{~mL})$ and dried over anhydrous $\mathrm{Na}_{2} \mathrm{SO}_{4}$, filtered and evaporated. The crude residue was redissolved in $\mathrm{CH}_{2} \mathrm{Cl}_{2}(5 \mathrm{~mL})$ and chromatographed on silica gel with petroleum ether/EtOAc mixtures of increasing polarity $(19.8: 0.2 \rightarrow 13.0: 7.0)$ for 1 and $(19.8: 0.2 \rightarrow 14.4: 5.6)$ for 2

\section{2-((E)-3,7-dimethylocta-2,6-dienyl)benzene-1,4-diol (1)}

Colorless viscous oil, $0.3726 \mathrm{~g} \mathrm{(28 \% ),}{ }^{1} \mathrm{H}-\mathrm{NMR}$ : 6.69 (d, $J=8.0$ $\mathrm{Hz}, 1 \mathrm{H}, \mathrm{H}-6) ; 6.61$ (d, $J=3.0 \mathrm{~Hz} 1 \mathrm{H}, \mathrm{H}-3) ; 6.58$ (dd, $J=3.0$ and $8.0 \mathrm{~Hz}, 1 \mathrm{H}, \mathrm{H}-5) ; 5.29$ (t, $J=7.0 \mathrm{~Hz}, 1 \mathrm{H}, \mathrm{H}-2$ '); 5.07 (t, $J=5.0 \mathrm{~Hz}$, 1H, H-6'); 4.75 (s, 1H, OH); 4.46 (s, 1H, OH); 3.30 (d, J = $7.0 \mathrm{~Hz}$, 2H, H-1'); 2.09 (m, 4H, H-5' and H-4'); 1.75 (s, 3H, H-10'); 1.69 (s, 3H, H-8'); 1.60 (s, 3H, H-9'). ${ }^{13} \mathrm{C}-\mathrm{NMR}: 149.3$ (C-1), 148.3 (C-4), 138.6 (C-3'), 132.0 (C-7'), 128.3 (C-2), 123.9 (C-6'), 121.3 (C-2'), 116.6 (C-3), 116.6 (C-6), 113.7 (C-5), 39.7 (C-4'), 29.7 (C-5'), 26.4 (C-1'), 25.7 (C-8'), 17.7 (C-9'), 16.2 (C-10'). IR ( $\left.\mathrm{cm}^{-1}\right)$ : 3385, 2966 , 2920, 1654, 1500, 1450, 1193. HRMS: $(\mathrm{M}+1)$ calcd. for $\mathrm{C}_{16} \mathrm{H}_{22} \mathrm{O}_{2}$ : 247.1620 , found: 247.1623 .

\section{4-methoxy-2-((E)-3,7-dimethylocta-2,6-dienyl)phenol (2)}

Colorless viscous oil, $0.1444 \mathrm{~g}(10 \%),{ }^{1} \mathrm{H}-\mathrm{NMR}$ : 6.74 (d, $J=8.5$ $\mathrm{Hz}, 1 \mathrm{H}, \mathrm{H}-6) ; 6.68$ (d, $J=3.0 \mathrm{~Hz}, 1 \mathrm{H}, \mathrm{H}-3) ; 6.65$ (dd, $J=8.5$ and $3.0 \mathrm{~Hz}, 1 \mathrm{H}, \mathrm{H}-5$ ); 5.31 (t, $J=7.0 \mathrm{~Hz}, 1 \mathrm{H}, \mathrm{H}-2$ '); 5.07 (t, $J=6.0 \mathrm{~Hz}$,

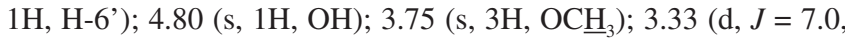
2H, H-1'); 2.08 (m, 4H, H-5' and H-4'); 1.76 (s, 3H, H-10'); 1.68 (s, 3H, H-8'); 1.60 (s, 3H, H-9'). ${ }^{13}$ C-NMR: 153.7 (C-4), 148.3 (C-1), 138.6 (C-3'), 132.0 (C-7'), 128.1 (C-2), 123.8 (C-6'), 121.4 (C-2'), 116.4 (C-6), 115.7 (C-3), 112.1 (C-5), $55.7\left(\mathrm{OCH}_{3}\right), 39.7$ (C-4'), 29.9 (C-5'), 26.5 (C-1'), 25.6 (C-8'), 17.7 (C-9'), 16.2 (C-10'). IR $\left(\mathrm{cm}^{-1}\right)$ : 3418, 2965, 2916, 1609, 1279, 1043. HRMS: $(\mathrm{M}+1)$ calcd. for $\mathrm{C}_{17} \mathrm{H}_{24} \mathrm{O}_{2}$ : 261.1776, found: 261.1779.

Synthesis of geranylhydroquinones derivatives (3-5)

\section{2-((E)-3,7-dimethylocta-2,6-dienyl)cyclohexa-2,5-diene-1,4-dione} (3)

The geranylhydroquinone $1(0.1444 \mathrm{~g}, 0.59 \mathrm{mmol})$ dissolved in dichloromethane $(20 \mathrm{~mL}), \mathrm{MnO}_{2}(0.05 \mathrm{~g}, 0.6 \mathrm{mmol})$ was added. The mixture was stirred at room temperature for $18 \mathrm{~h}$. After filtration, the solution was evaporated to dryness to afford the crude reaction product, which yielded $117.8 \mathrm{mg}$ (82\% Yield) of compound $\mathbf{3}$, after column chromatography (eluent dichloromethane), colorless viscous oil. ${ }^{1} \mathrm{H}-\mathrm{NMR}$ : 6.75 (d, $\left.J=10.0 \mathrm{~Hz}, 1 \mathrm{H}, \mathrm{H}-6\right) ; 6.70$ (dd, $J=2.0$ and $10.0 \mathrm{~Hz}, 1 \mathrm{H}, \mathrm{H}-5) ; 6.52$ (dd, $J=2.0$ and $4.0 \mathrm{~Hz}, 1 \mathrm{H}, \mathrm{H}-3) ; 5.14$ (t, $J$ $=7.0 \mathrm{~Hz}, 1 \mathrm{H}, \mathrm{H}-2$ ') 5.07 (t, $J=5.0 \mathrm{~Hz}, 1 \mathrm{H}, \mathrm{H}-6$ ') 3.12 (d, $J=7.0$, 2H, H-1'); 2.07 (m, 4H, H-5' and H-4'); 1.68 (s, 3H, H-10'); 1.62 (s, 3H, H-8'); 1.59 (s, 3H, H-9'). ${ }^{13} \mathrm{C}-\mathrm{NMR}: 187.9$ (C-1), 187.6 (C-4), 148.5 (C-2), 140.1 (C-3'), 136.7 (C-5), 136.3 (C-6), 132.3 (C-3), 131.8 (C-7'), 123.9 (C-6'), 117.7 (C-2'), 39.6 (C-4'), 27.3 (C-5'), 26.4 (C-1'), 25.7 (C-8'), 17.7 (C-9'), 16.1 (C-10'). IR ( $\left.\mathrm{cm}^{-1}\right)$ : 2919, 1648, 1655, 1197. HRMS: $(\mathrm{M}+1)$ calcd. for $\mathrm{C}_{16} \mathrm{H}_{20} \mathrm{O}_{2}: 245.1463$, found: 245.1468 .

\section{1,4-dimethoxy-2-((E)-3,7-dimethylocta-2,6-dienyl)benzene (4)}

Potassium carbonate $(0.1 \mathrm{~g}, 0.7 \mathrm{mmol})$ and dimethyl sulphate $(0.12 \mathrm{~g}, 0.9 \mathrm{mmol})$ were added to geranylhydroquinone $\mathbf{1}(0.1139 \mathrm{~g}$, $0.46 \mathrm{mmol})$ dissolved in acetone $(30 \mathrm{~mL})$. The mixture was stirred at room temperature for $24 \mathrm{~h}$. After filtration, the solution was evaporated to dryness. Dilution with diethyl ether was followed by washing with $\mathrm{NaOH}$ solution (5\%) and the organic phase was then dried over anhydrous $\mathrm{Na}_{2} \mathrm{SO}_{4}$. The solution was evaporated to dryness to afford the crude reaction product, obtaining $54.4 \mathrm{mg}$ (44\% Yield) of compound $\mathbf{4}$ after column chromatography (eluent to hexane/ethyl acetate, 19.8:0.2 $\rightarrow$ 18.0:2.0), colorless viscous oil. ${ }^{1} \mathrm{H}-\mathrm{NMR}: 6.77$ (d, $J=8,8 \mathrm{~Hz}, 1 \mathrm{H}, \mathrm{H}-6) ; 6.74(\mathrm{~d}, J=3.0 \mathrm{~Hz}, 1 \mathrm{H}, \mathrm{H}-3) ; 6.68$ (dd, $J=3.0$ and $8.8 \mathrm{~Hz}, 1 \mathrm{H}, \mathrm{H}-5) ; 5.31(\mathrm{t}, J=7.0 \mathrm{~Hz}, 1 \mathrm{H}, \mathrm{H}-2$ '); 5.11 (bt, $J=5.0$

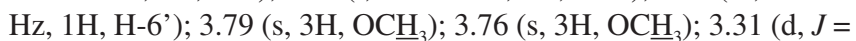
$7.0 \mathrm{~Hz}, 2 \mathrm{H}, \mathrm{H}-1^{\prime}$ ); 2.08 (m, 4H, H-5' and H-4'); 1.74 (s, 3H, H-10'); 1.70 (s, 3H, H-8'); 1.68 (s, 3H, H-9'). ${ }^{13} \mathrm{C}-\mathrm{NMR}: 153.6$ (C-4), 151.7 (C-1), 136.4 (C-3'), 131.5 (C-2), 131.4 (C-7'), 124.3 (C-6'), 122.1 (C-2'), 116.0 (C-3), 111.2 (C-6), 110.5 (C-5), 56.1 (C-7), 55.6 (C-8), 39.8 (C-4'), 28.2 (C-5'), 26.7 (C-1'), 25.7 (C-8'), 17.7 (C-9'), 16.1 (C-10'). IR ( $\left.\mathrm{cm}^{-1}\right): 2925,2853,1590,1463,1052$. HRMS: $(\mathrm{M}+1)$ calcd. for $\mathrm{C}_{18} \mathrm{H}_{26} \mathrm{O}_{2}: 275.1933$, found: 275.1937.

4-methoxy-2-((E)-3,7-dimethylocta-2,6-dienyl)phenyl acetate (5)

Acetic anhydride $(1.4 \mathrm{~g}, 1.3 \mathrm{~mL}, 13 \mathrm{mmol})$ and dimethylaminopyridine (DMAP, $0.02 \mathrm{~g}, 0.16 \mathrm{mmol}$ ) were added to geranyl-4-methoxyphenol 2 ( $0.1306 \mathrm{~g}, 0.5 \mathrm{mmol})$ dissolved in dichloromethane $(20 \mathrm{~mL})$. The mixture was stirred at room temperature for $2 \mathrm{~h}$. The organic phase was washed with water and subsequently dried over anhydrous $\mathrm{Na}_{2} \mathrm{SO}_{4}$. The solution was evaporated to dryness to afford the crude reaction product, yielding $31.7 \mathrm{mg}$ (22\% Yield) of compound $\mathbf{5}$ after column chromatography (eluent to hexane/ethyl acetate, 19.8:0.2 $\rightarrow$ 18.0:2.0), colorless viscous oil. ${ }^{1} \mathrm{H}-\mathrm{NMR}: 6.93$ (d, $J=8.7 \mathrm{~Hz}, 1 \mathrm{H}, \mathrm{H}-6) ; 6.76$ (d, $J=2.7 \mathrm{~Hz}, 1 \mathrm{H}, \mathrm{H}-3) ; 6.73$ (dd, $J$ $=8.7$ and $2.7 \mathrm{~Hz}, 1 \mathrm{H}, \mathrm{H}-5) ; 5.24$ (t, $J=7.0 \mathrm{~Hz}, 1 \mathrm{H}, \mathrm{H}-2$ '); 5.10 (bt, $J=6.0 \mathrm{~Hz}, 1 \mathrm{H}, \mathrm{H}-6$ '); 3.78 (s, 3H, H-8); 3.20 (d, $J=7.0,2 \mathrm{H}, \mathrm{H}-1$ '); 2.29 (s, 3H, H-7); 2.08 (m, 4H, H-5' and H-4'); 1.68 (s, 6H, H-8' and H-10'); 1.60 (s, 3H, H-9'). ${ }^{13} \mathrm{C}-\mathrm{NMR}: 169.9\left(\mathrm{COCH}_{3}\right), 157.4$ (C-4), 142.5 (C-1), 137.2 (C-3'), 134.5 (C-2), 131.6 (C-7'), 124.1 (C-6'), 122.7 (C-6), 121.2 (C-2'), 115.4 (C-3), 111.5 (C-5), 55.5 (C-8), 39.6 (C-4'), 28.7 (C-5'), 26.6 (C-1'), 25.6 (C-8'), 20.8 (C-7), 17.7 (C-9'), 16.1 (C-10'). IR ( $\left.\mathrm{cm}^{-1}\right)$ : 2924, 1762, 1496, 1195, 1041. HRMS: (M +1 ) calcd. for $\mathrm{C}_{19} \mathrm{H}_{26} \mathrm{O}_{3}: 303.1882$, found: 303.1885 .

\section{Bioactivity: cell growth inhibition assay}

The colorimetric assay using sulforhodamine B (SRB) following adaptation of the method described by Skehan et al., ${ }^{14}$ was used. Cells were seeded onto 96-well microtiter plates, at $5 \times 10^{3}$ cells per well in aliquots of $100 \mu \mathrm{L}$ of DMEM/F-12 medium, and were allowed to attach to the plate surface by growing in drug-free medium for $18 \mathrm{~h}$. Subsequently, compounds samples were added in aliquots (dissolved in $\mathrm{EtOH} / \mathrm{H}_{2} \mathrm{O}$ ) to achieve a final concentration of $12.5,25,50$ and $100 \mu \mathrm{M}$. The same ethanol/ $\mathrm{H}_{2} \mathrm{O}$ solution was used as a negative control. Moreover, dunnione was used as a positive control although this compound did not show structural similarity with the analysed compounds. After $72 \mathrm{~h}$ exposure, in vitro cytotoxicity was measured by the SRB dye assay. Cells were fixed by adding cold $50 \%$ (wt/vol) trichloroacetic acid (TCA, $25 \mu \mathrm{L}$ ) and incubating for $60 \mathrm{~min}$ at $4{ }^{\circ} \mathrm{C}$. Plates were washed with deionized water and dried; SRB solution $(0.1 \% \mathrm{wt} / \mathrm{vol}$ in $1 \%$ acetic acid, $50 \mu \mathrm{L})$ was added to each microtiter well and incubated for $30 \mathrm{~min}$ at room temperature. Unbound SRB was removed by washing with $1 \%$ acetic acid. Plates were air-dried and bound stain was solubilized with Tris base $(100 \mu \mathrm{L}, 10 \mathrm{mM})$. Optical densities were read on an automated spectrophotometer plate reader at a single wavelength of $540 \mathrm{~nm}$. Values shown are \% viability $v s . \mathrm{Ctrl}+\mathrm{SD}, \mathrm{n}=$ four independent experiments in triplicate.

\section{CONCLUSIONS}

In summary natural geranylhydroquinone $\mathbf{1}$ and geranyl4-methoxyphenol 2 were prepared. These compounds were obtained by Electrophilic Aromatic Substitution (EAS) coupling reactions between geraniol with 1,4-hydroquinone and 4-methoxyphenol. 
Furthermore, natural geranylquinone $\mathbf{3}$ and geranylhydroquinone derivatives (4-5) were obtained by chemical transformations of the coupling compounds $\mathbf{1}$ and $\mathbf{2}$. Compounds $\mathbf{1}$ and $\mathbf{3}$ showed cytotoxic activity against prostate cancer cell line PC-3, as well as breast cancer cell lines MCF-7 and MDA-MB231. However the citotoxicity was lower than the positive control (dunnione). Moreover, these compounds showed some selectivity for the cancer cells versus fibroblast cells. The increased citotoxicity induced in the cell lines by compounds $\mathbf{1}$ and $\mathbf{3}$ due to the presence of hydroquinone or quinone moiety in the structure of these compounds versus compounds $\mathbf{2 , 4}$ and $\mathbf{5}$.

\section{SUPPLEMENTARY MATERIAL}

${ }^{1} \mathrm{H}$ NMR and ${ }^{13} \mathrm{C}$ NMR spectra of compounds 1-5 are available free of charge at http://quimicanova.sbq.org.br as a PDF file.

\section{ACKNOWLEDGEMENTS}

The authors thank to Programa Incentivo a la Iniciación Científica (PIIC QUI-2010 for E.B.M.) and grant No 13.09.42 (2009-2010) and 13.11.36 (2011-2012) of the Dirección General de Investigación y Postgrado (DGIP) from the Universidad Técnica Federico Santa María for financial support.

\section{REFERENCES}

1. Thomson, R. H.; Naturally Occurring Quinones, Academic: London, 1971; Pennock, J. F. In Terpenoids in Plants; Pridham, J. B., ed.; Academic: London, 1967.

2. Faulkner, D. J.; Nat. Prod. Rep. 1986, 3, 1; Ochi, M.; Kotsuki, H.; Inoue, S.; Taniguchi, M.; Chem. Lett. 1979, 831; Capon, R. J.; Ghisalberti, E. L.; Jefferies, P. R.; Phytochemistry 1981, 20, 2598; Gerwick, W. H.; Fenical, W.; J. Org. Chem. 1981, 46, 22.
3. Fenical, W. In Marine Natural Products, Chemical and Biological Perspectives; Scheuer, P. J., ed.; Academic Press: New York, 1978, vol. 2; Minale, L. In Marine Natural Products, Chemical and Biological Perspectives; Scheue, P. J., ed.; Academic Press: New York, 1978, vol. 1, p. 220; De Rosa, S.; Crispino, A.; De Giulio, A.; Iodice, C.; Milone, A.; J. Nat. Prod. 1995, 58, 1450; Bifulco, G. I.; Minale, L.; Riccio, R.; J. Nat. Prod. 1995, 58, 1444 .

4. Bowden, B. F.; Coll, J. C.; Aust. J. Chem. 1981, 34, 2677.

5. Ravi, B. N.; Wells, R. J.; Aust. J. Chem. 1982, 35, 105.

6. Howard, B. M.; Clarkson, K.; Bernstein, R. L.; Tetrahedron Lett. 1979, 20, 4449; Targett, N. M.; Keeran, W. S.; J. Nat. Prod. 1984, 47, 556; Guella, G. I.; Mancini, P. F.; Helv. Chim. Acta 1987, 70, 621; Faulkner, D. J.; Nat. Prod. Rep. 1993, 10, 497; Fu, X.; Bilayet Hossain, M.; van der Helm. D.; J. Am. Chem. Soc. 1994, 116, 12125; Fu, X.; Bilayet Hossain, M.; Schmitz, F.; van der Helm, D.; J. Org. Chem. 1997, 62, 3810.

7. De Rosa, S.; De Giulio, A.; Iodice, C.; J. Nat. Prod. 1994, 57, 1711.

8. Fedorov, S. N.; Radchenko, O. S.; Shubina, L. K.; Balaneva, N. N.; Bode, A. M.; Stonik, V. A.; Dong, Z.; Pharm. Res. 2006, 23, 70.

9. Inouye, H.; Tokura, K.; Tobita, S.; Chem. Ber. 1968, 101, 4057; Takenaka, K.; Tanigaki, Y.; Patil, M. L.; Rao, L.; Takizawa, S.; Suzuki, T.; Sasai, H.; Tetrahedron: Asymmetry 2010, 21, 767; Espinoza, L.; Baeza, E.; Catalán, K.; Osorio, M.; Carrasco, H.; Cuellar, M.; Villena, J.; Molecules 2010, 15, 6502 .

10. Aknin, M.; Dayan, T.; Rudi, A.; Kashman, Y.; Gaydouc, E.; J. Agric. Food Chem. 1999, 47, 4175.

11. Shubina, L.; Fedorov, S. N.; Radchenko, O. S.; Balaneva, N. N.; Kolesnikova, S. A.; Dmitrenok, P. S.; Zigang-Dong, A. B.; Stonik, V. A.; Tetrahedron Lett. 2005, 46, 559.

12. Naruta, Y.; Maruyama, K.; Org. Synth. 1993, 71, 125.

13. Julia, M.; Schmitz, C.; Tetrahedron 1986, 42, 2485.

14. Vichai, V.; Kanyawim K.; Nature Protocols 2006, 1, 1112; Skehan, P.; J. Natl. Cancer Inst. 1990, 82, 1107. 


\section{SYNTHESIS OF GERANYLHYDROQUINONE DERIVATIVES WITH POTENCIAL CYTOTOXIC ACTIVITY}

Evelyn Baeza, Karen Catalán, Hugo Peña-Cortés and Luis Espinoza*

Departamento de Química, Universidad Técnica Federico Santa María, Valparaíso, Chile Joan Villena

Facultad de Medicina, Universidad de Valparaíso / Centro Regional de Estudios en Alimentos Saludables, Valparaíso, Chile. Héctor Carrasco

Departamento de Ciencias Químicas, Universidad Andrés Bello, Campus Viña del Mar, Chile

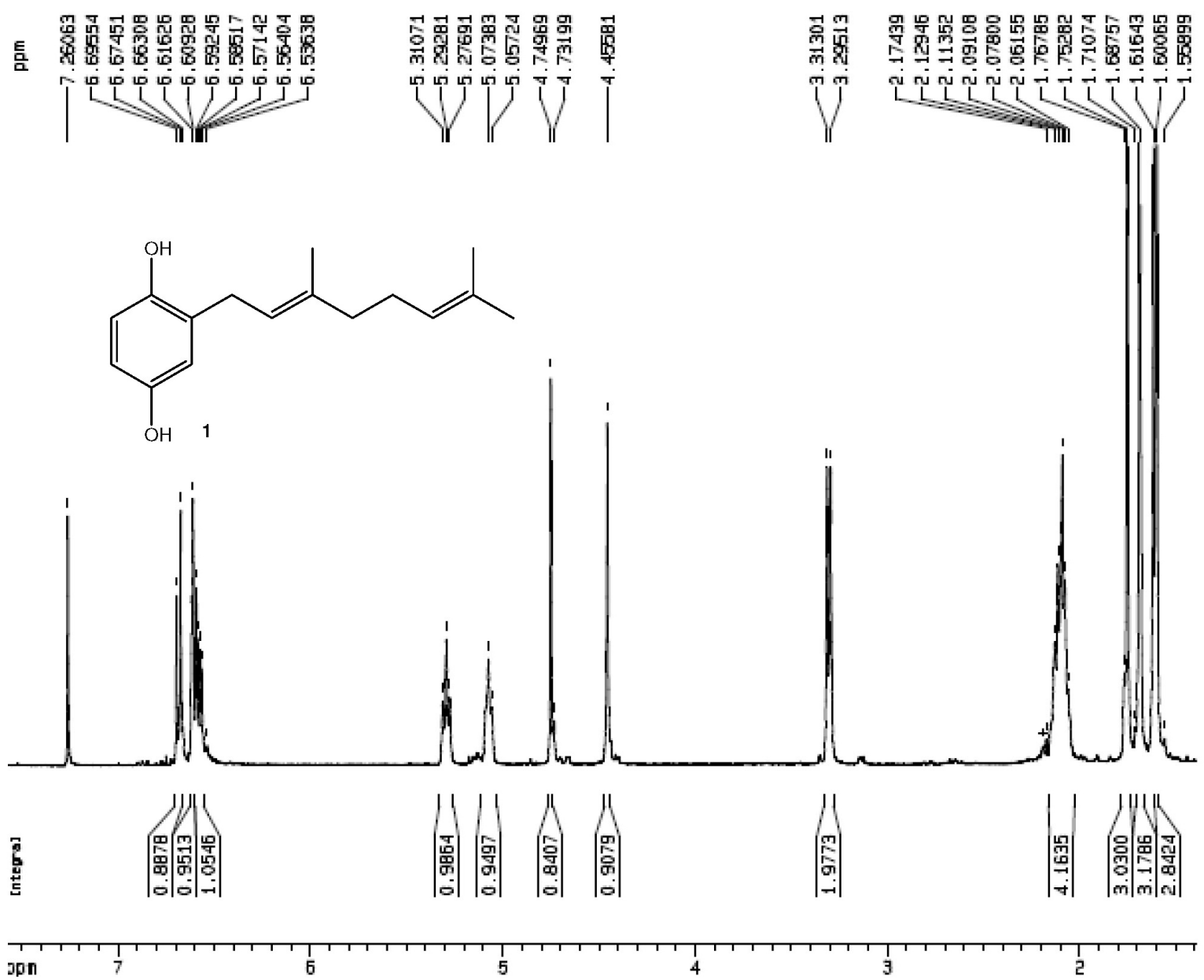

Figure $1 S .{ }^{1} \mathrm{H}$ NMR $(400 \mathrm{MHz}, \mathrm{CDCl} 3)$ of compounds 1 


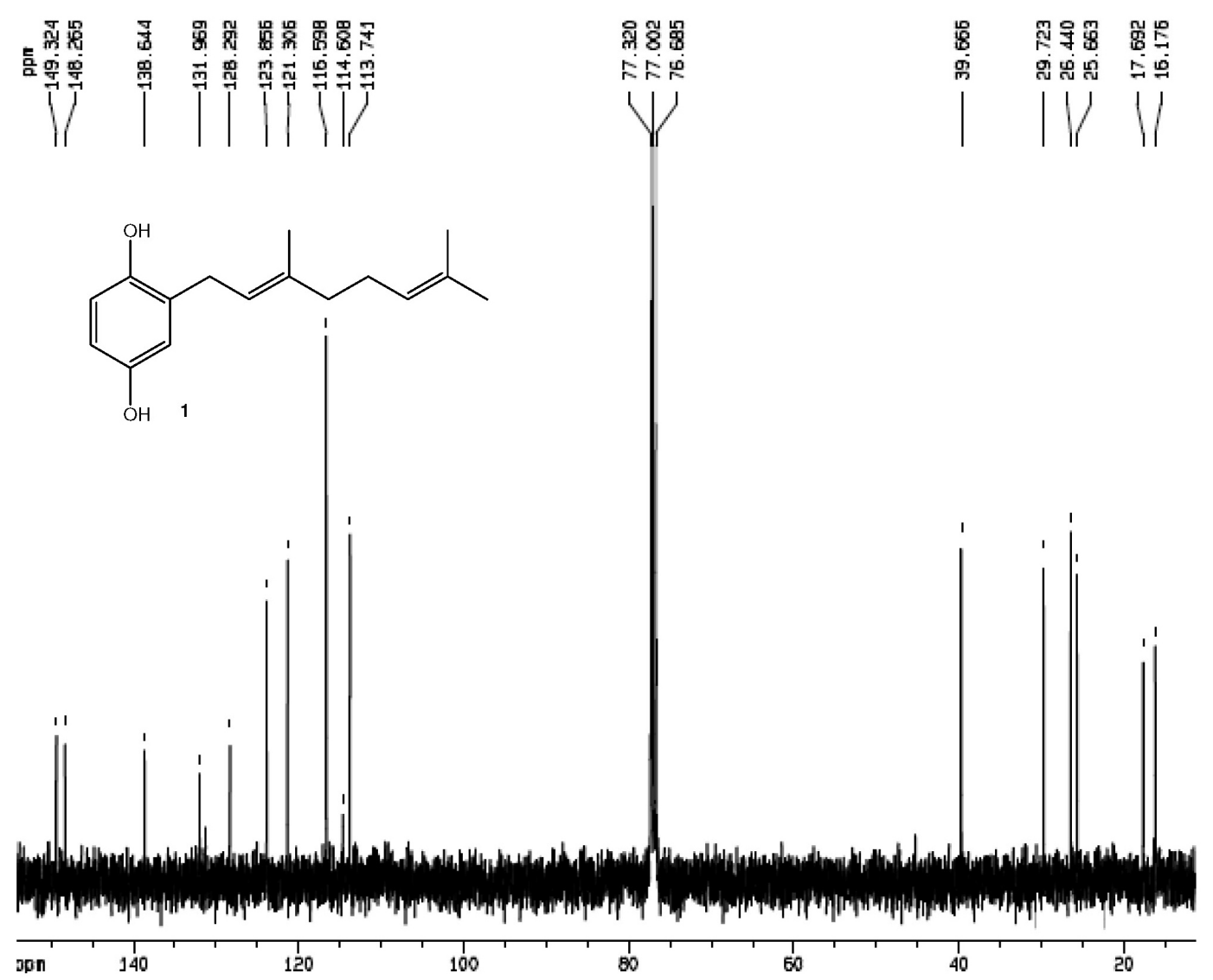

Figure $2 \mathrm{~S} .{ }^{13} \mathrm{C} N \mathrm{NR}(100 \mathrm{MHz}, \mathrm{CDCl})$ of compounds $\mathbf{I}$
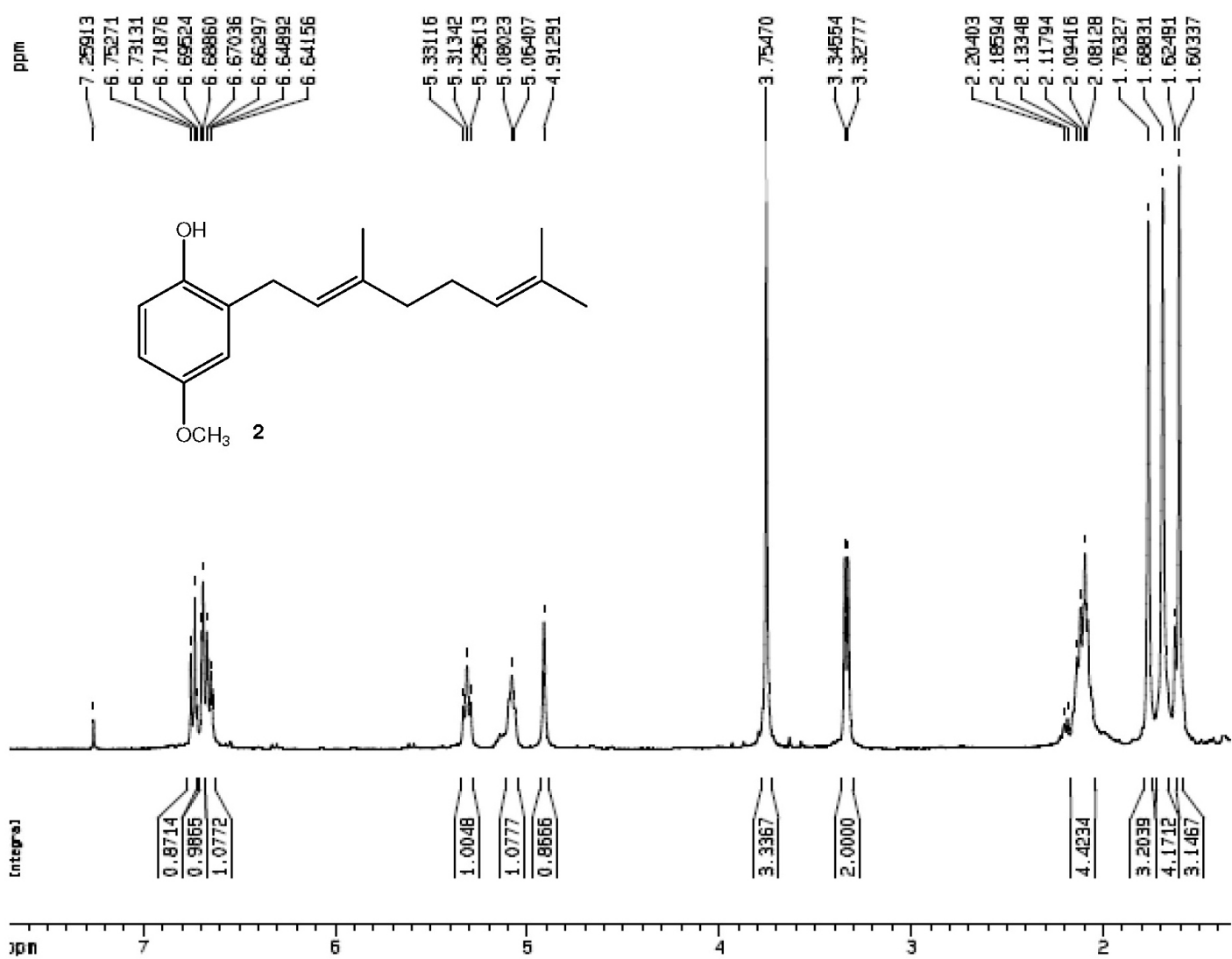

Figure 3S. ${ }^{l} \mathrm{H}$ NMR (400 MHz, CDCl3) of compounds 2 


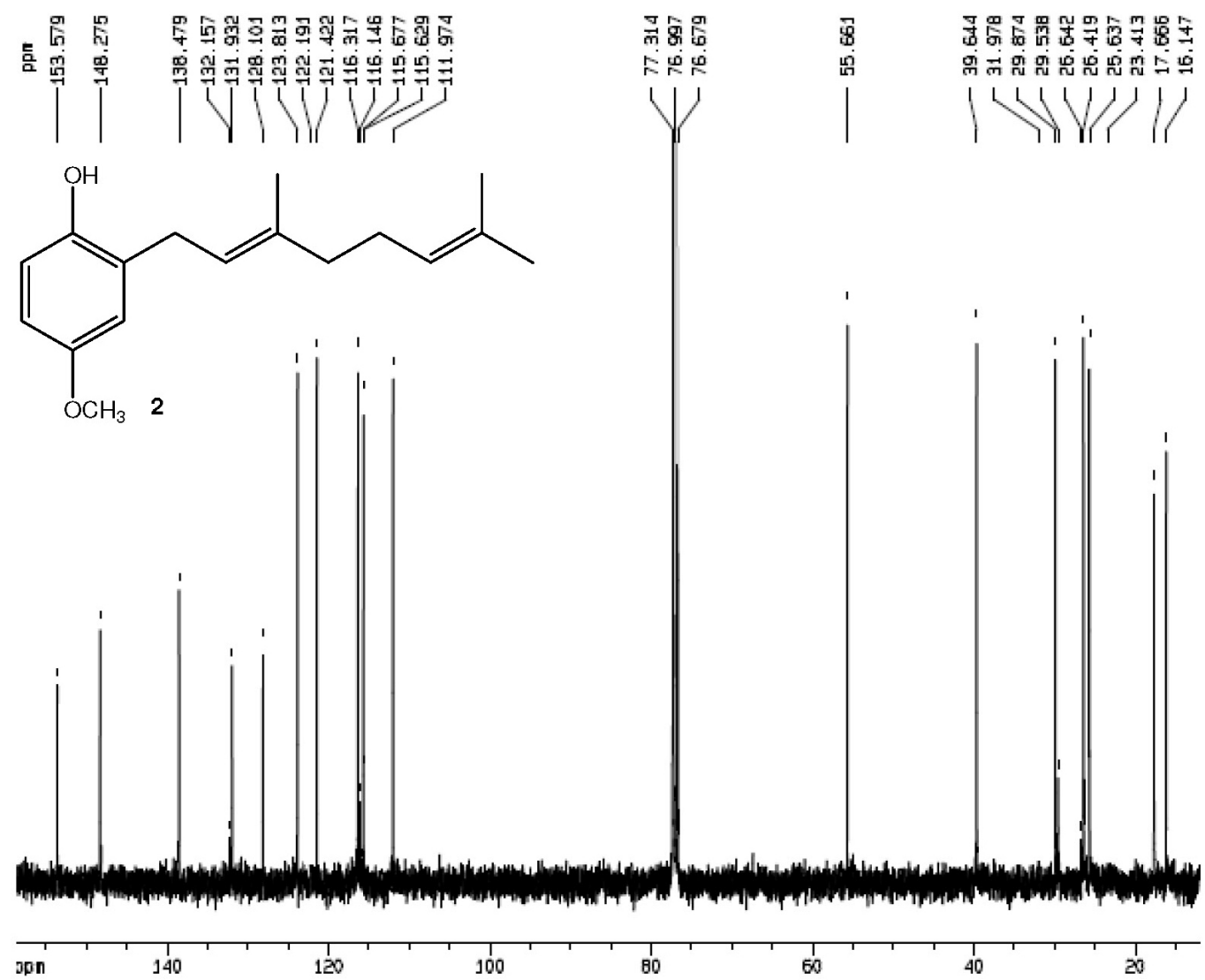

Figure $4 \mathrm{~S} .{ }^{13} \mathrm{C} \mathrm{NMR}(100 \mathrm{MHz}, \mathrm{CDCl} 3)$ of compounds 2
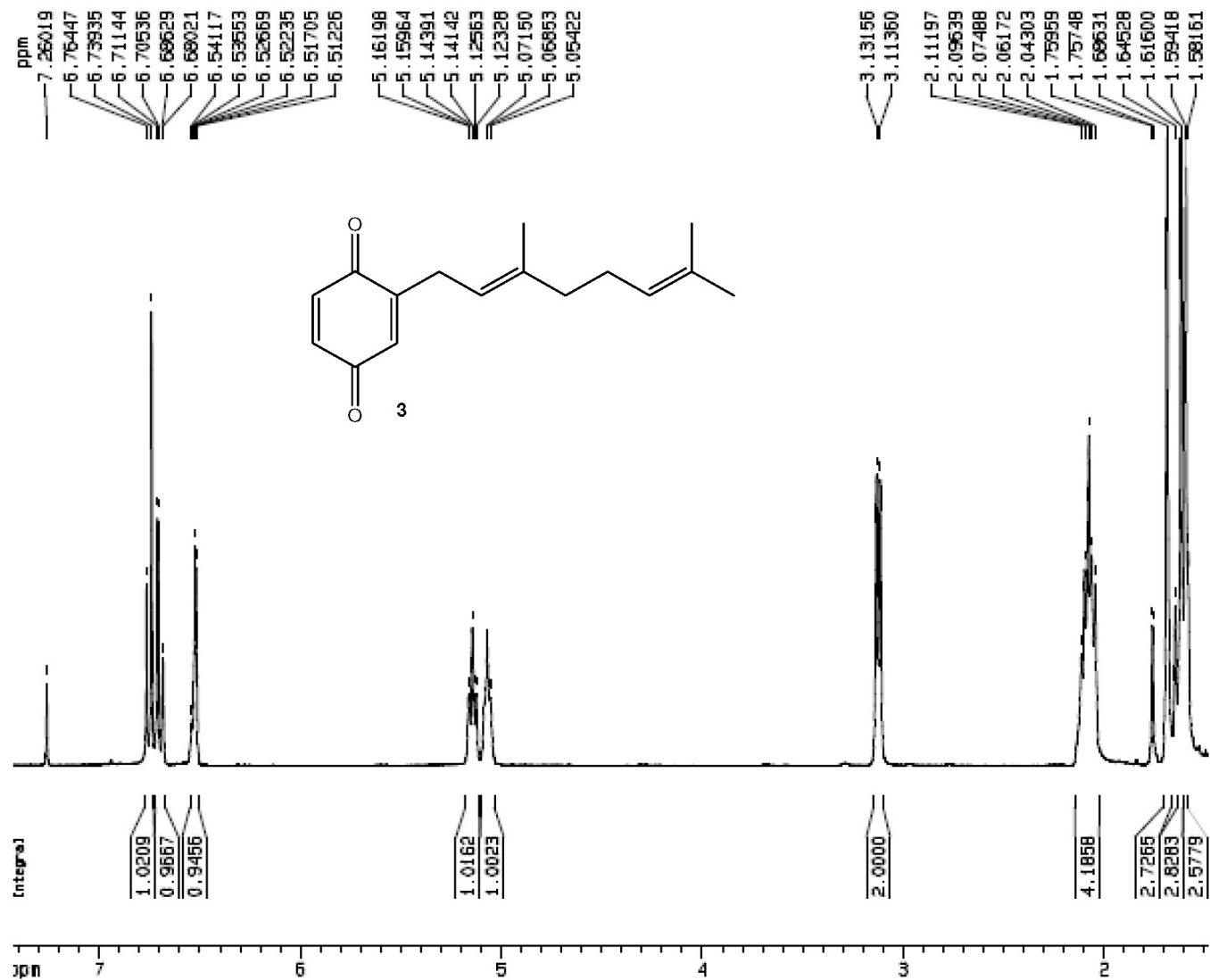

Figure 5S. ${ }^{1} \mathrm{H}$ NMR (400 MHz, CDCl3) of compounds 3 


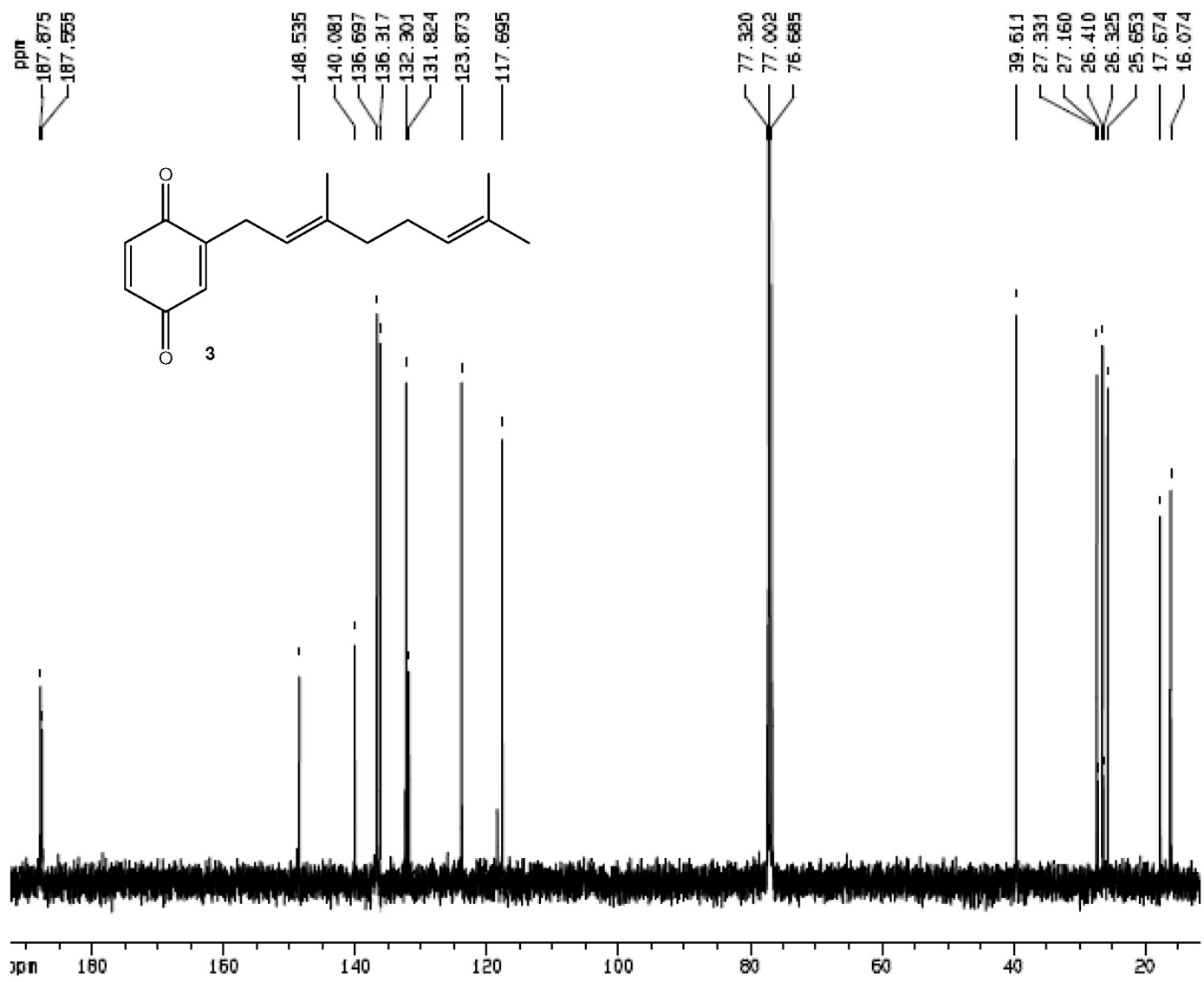

Figure $6 \mathrm{~S} .{ }^{13} \mathrm{C} \mathrm{NMR}(100 \mathrm{MHz}, \mathrm{CDCl} 3)$ of compounds 3
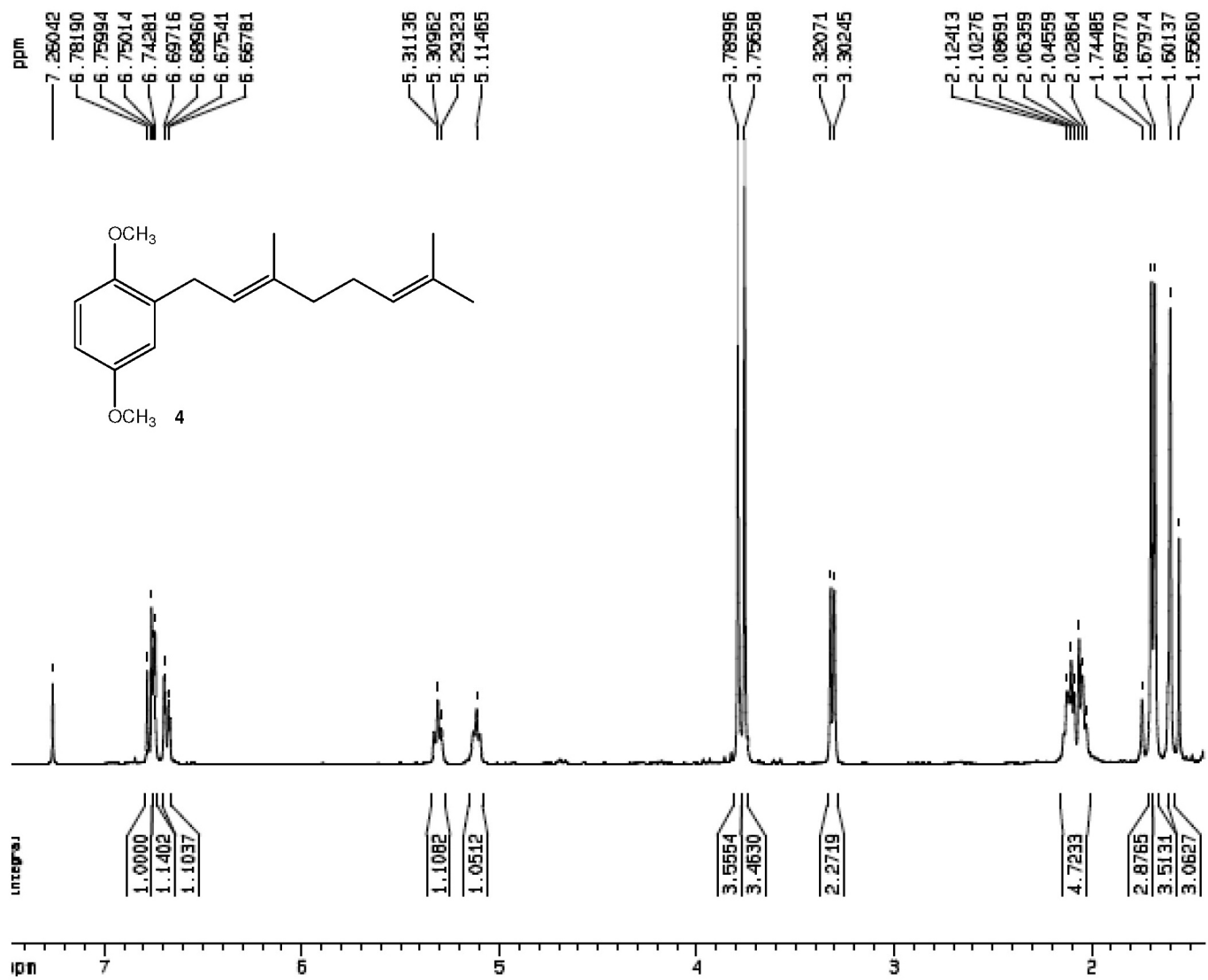

Figure $7 \mathrm{~S} .{ }^{1} \mathrm{H}$ NMR $(400 \mathrm{MHz}, \mathrm{CDCl})$ of compounds 4 


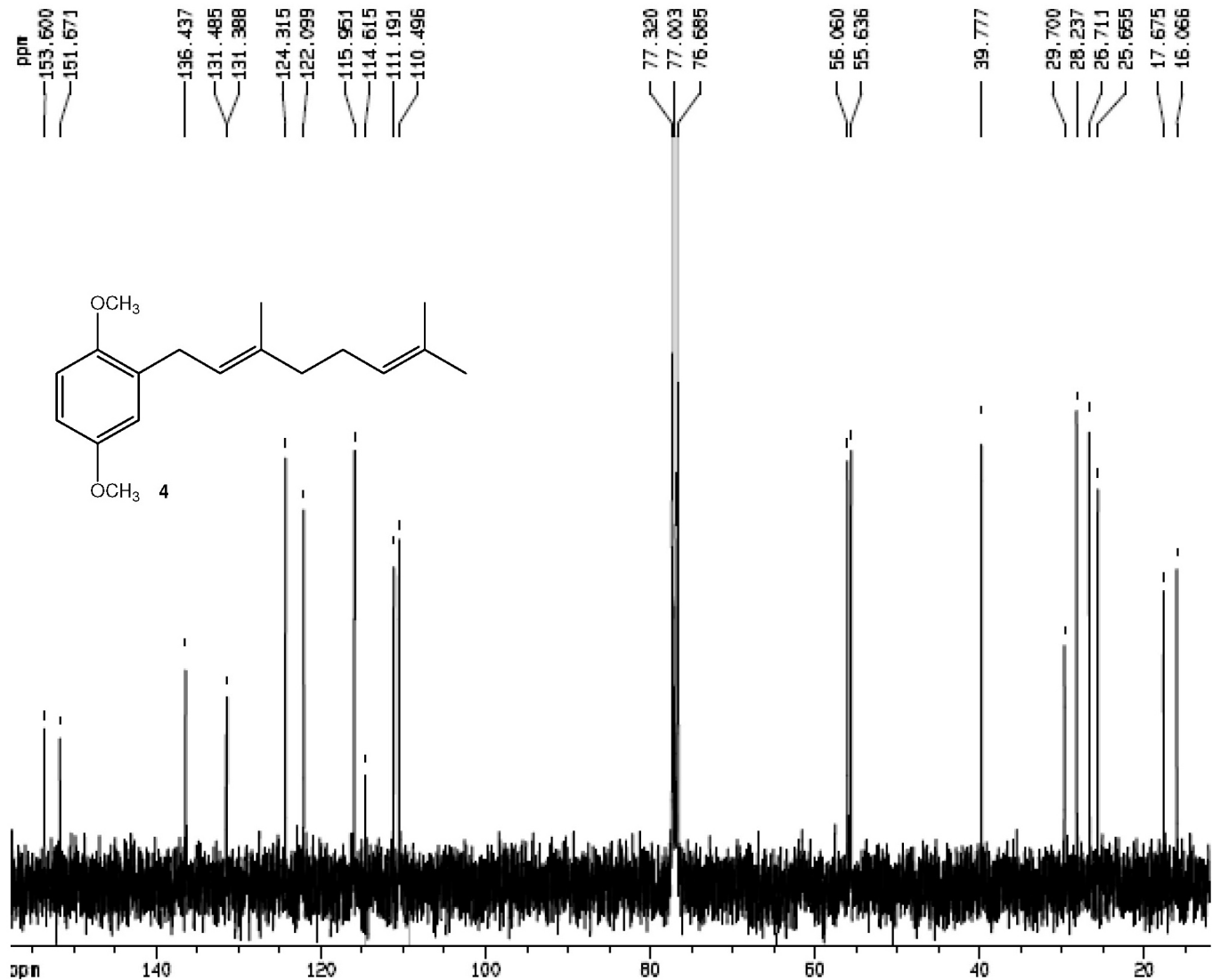

Figure $8 \mathrm{~S} .{ }^{13} \mathrm{C} \mathrm{NMR}(100 \mathrm{MHz}, \mathrm{CDCl} 3)$ of compounds 4

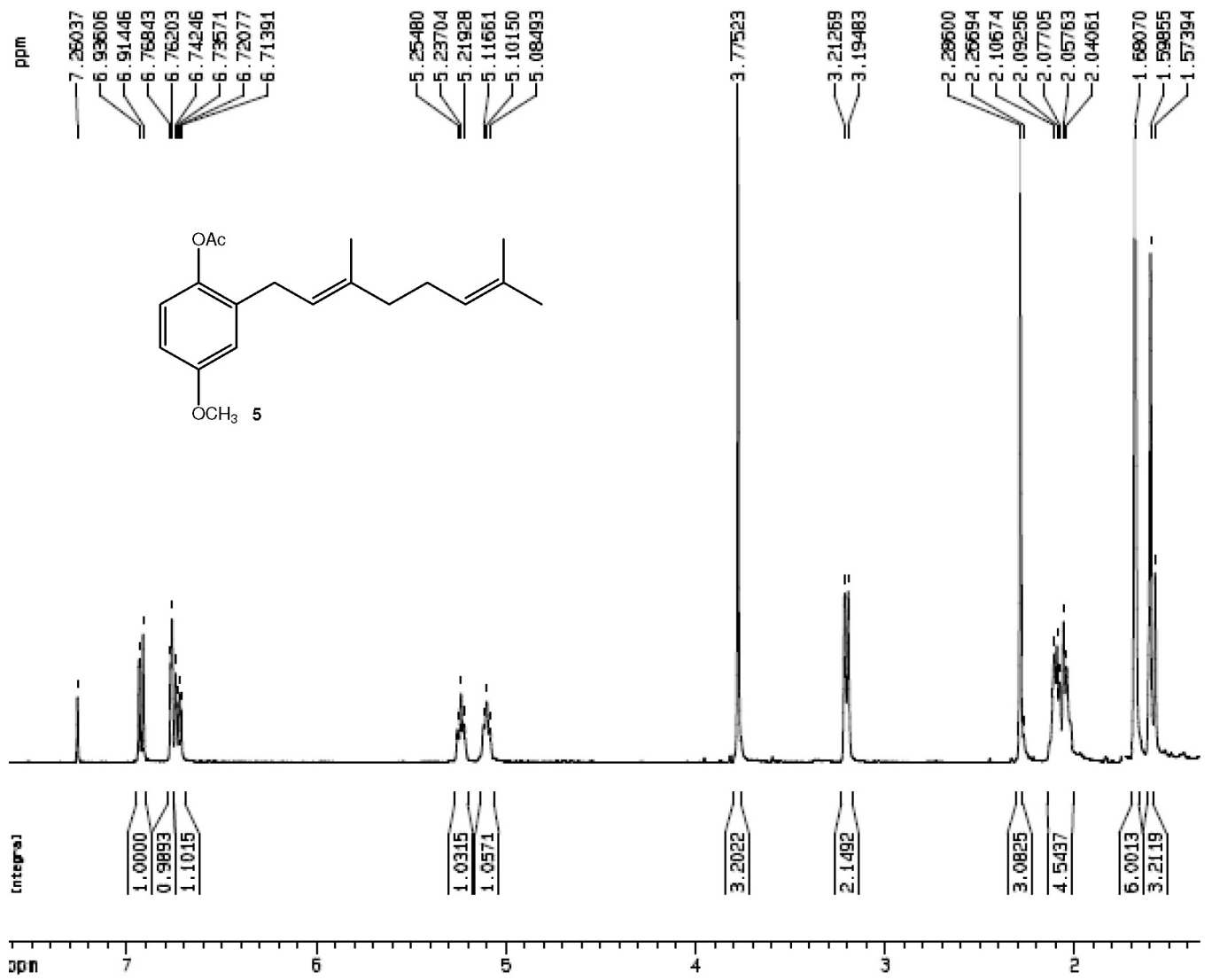

Figure 9S. ${ }^{1} \mathrm{H}$ NMR (400 $\left.\mathrm{MHz}, \mathrm{CDCl} 3\right)$ of compounds 5 


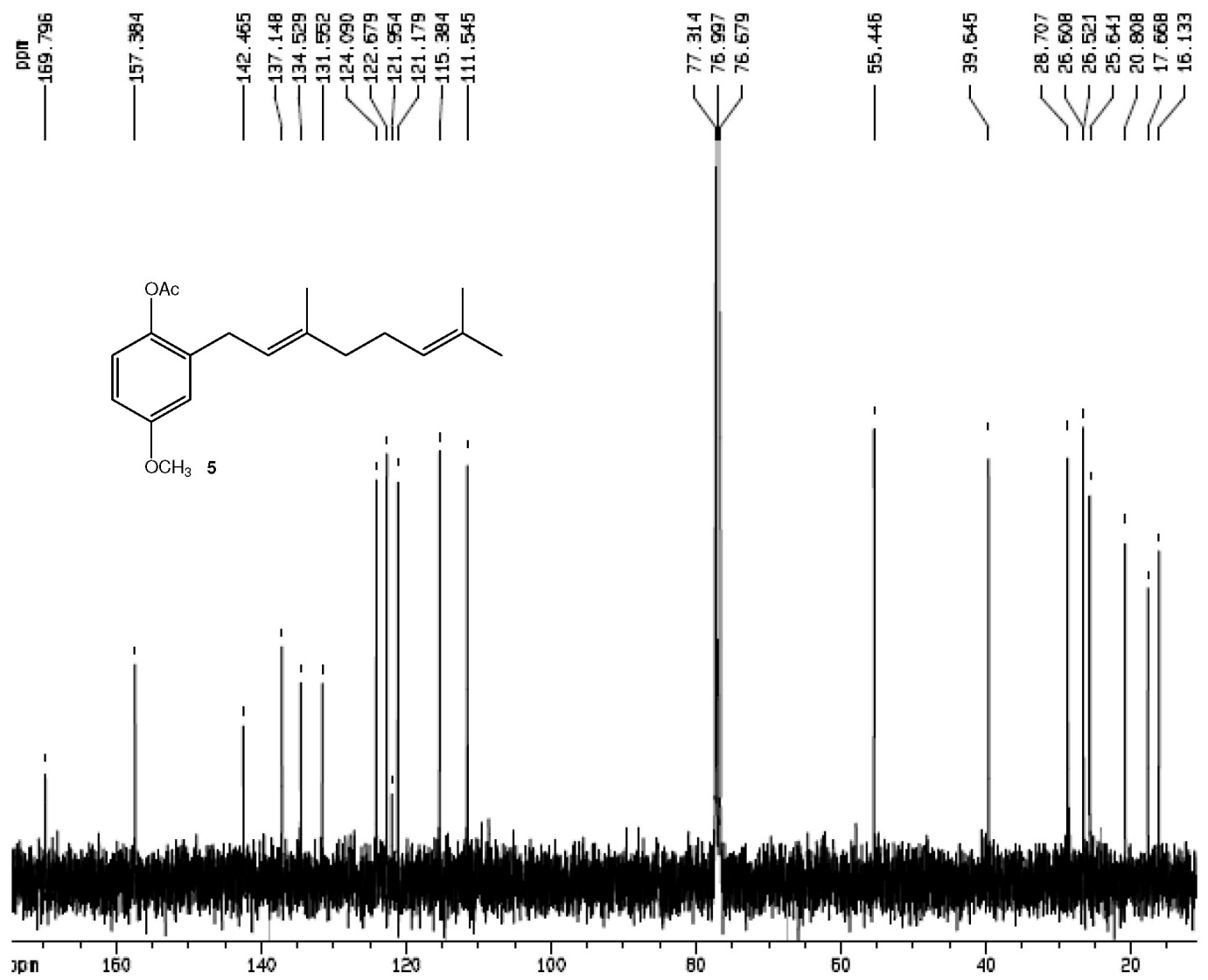

Figure 10S. ${ }^{13} \mathrm{C} \mathrm{NMR}(100 \mathrm{MHz}, \mathrm{CDCl} 3)$ of compounds 5 